\title{
Age castration of Nellore males on the profile of fatty acids of meat
}

\section{Idade à castração de machos Nelore sobre o perfil de ácidos graxos da carne}

\author{
Regis Luis Missio ${ }^{1 *}$; João Restle²; Aline Kelherman de Freitas 3 ; Moacir Evandro \\ Lage $^{2}$; Paulo Santana Pacheco ${ }^{4}$; Ubirajara Oliveira Bilego5; João Teodoro Pádua²
}

\begin{abstract}
This study aimed to evaluate the cholesterol content, $\alpha$-tocopherol and fatty acids in the meat of Nellore young bulls or steers castrated at different ages, 13 or 18 months. The animals were confined for 100 days and slaughtered at 22 months of age. The experimental design was completely randomized with three treatments, using 12 repetitions. The levels of palmitic acid (26.39\%), stearic (24.39\%), myristic $(3.01 \%)$ and total saturated fatty acids were not altered by sexual condition or castration age. Oleic was the fatty acid with the highest average participation in the meat $(34.54 \%)$, and lower content in the meat of young bulls in relation to the castrated. The content of total unsaturated fatty acids was lower in the young bulls in relation to castrated at 18 months, which did not differ from castrated at 12 months. The content of total polyunsaturated fatty acids was increased by elevation of the castration age, being similar between young bulls and castrated at 18 months. The ratio $\omega 6 / \omega 3$ was not altered by sexual condition or castration age. Castration at the beginning of the finishing period increases the content of beneficial fatty acids to health in relation to castrated in the first third of backgrounding.
\end{abstract}

Key words: Unsaturated fatty acids. Saturated fatty acids. Linoleic. Oleic.

\section{Resumo}

Objetivou-se avaliar o conteúdo de colesterol, $\alpha$-tocoferol e ácidos graxos da carne de machos inteiros ou castrados em diferentes idades (13 ou 18 meses) da raça Nelore. Os animais foram confinados por 100 dias e abatidos com 22 meses de idade. O delineamento experimental utilizado foi o inteiramente casualizado com três tratamentos, utilizando-se 12 repetições. Os teores dos ácidos palmítico $(26,39 \%)$, esteárico $(24,39 \%)$, mirístico $(3,01 \%)$ e ácidos graxos saturados totais não foram alterados pela condição sexual e/ou idade à castração. $\mathrm{O}$ oleico foi o ácido graxo com maior participação média na carne $(34,54 \%)$, com menor participação na carne dos inteiros em relação aos castrados. O teor de ácidos graxos insaturados totais foi menor na carne dos inteiros em relação aos castrados com 18 meses, que não diferiram dos castrados aos 12 meses. $\mathrm{O}$ teor dos ácidos graxos poliinsaturados foi aumentado pela elevação da idade à castração, sendo similar entre inteiros e castrados aos 18 meses. A relação $\omega 6 /$ $\omega 3$ não foi alterada pela condição sexual e/ou idade à castração. A castração no início do período de

1 Prof. Dr., Departamento de Agronomia, Universidade Tecnológica Federal do Paraná, UTFPR, Pato Branco, PR, Brasil. E-mail regisluismissio@gmail.com

2 Profs., Drs., Departamento de Zootecnia, Universidade Federal de Goiás, UFG, Goiânia, GO, Brasil. E-mail: jorestle@terra.com. br; moacir@ufg.br; teodoro@ufg.br

3 Zootecnista, Curso de Mestrado em Ciência Animal, UFG, Goiânia, GO, Brasil. E-mail: akfreitas@hotmail.com

4 Prof. Dr., Departamento de Zootecnia, Universidade Federal de Santa Maria, UFSM, Santa Maria, RS, Brasil. E-mail: pacheco. dz.ufsm@hotmail.com

5 Zootecnista, M.e., Pesquisador, Cooperativa Agroindustrial dos Produtores Rurais do Sudeste Goiano, COMIGO, Rio Verde, GO, Brasil. E-mail: birabilego@hotmail.com

* Author for corrrespondence 
terminação aumenta o conteúdo de ácidos graxos benéficos à saúde em relação aos castrados no terço inicial da recria.

Palavras-chave: Ácidos graxos insaturados. Ácidos graxos saturados. Linoleico. Oleico.

\section{Introduction}

In Brazil, a significant proportion of the cattle that are slaughtered are intact males (bulls), which produce darker, harder meat due to increased preslaughter excitability (KUSS et al., 2010) and have lower body fat (RODRIGUES; ANDRADE, 2004). The higher levels of insoluble collagen in bulls (DESTEFANIS et al., 2003) and muscle calpastatin (MICOL et al., 2009) make their meat less tender. Grass finishing, on the other hand, responsible for the high slaughter age and low carcasses finish, coupled with the large participation of Nellore in the herd $(80 \%$ of the herd are Nellore or Nellorecross) and cooling rate of carcasses, accent softness, and color issues (FELÍCIO, 1994). This contributes significantly to the low international acceptability of Brazilian beef (PEREIRA et al., 2013).

Paradoxically, meat from bulls can be a healthier alternative. Daniel et al. (2010) assessed the meat consumption data in the United States and reported that concerns about the consumption of saturated fat and cholesterol from red meat led to reduced consumption of red meat and increased poultry meat intake as early as the 1980s. Although castration results in important benefits to the appearance of the meat, it tends to raise the level of cholesterol and reduce the content of fatty acids (polyunsaturated and monounsaturated), reducing the health value of the meat (RUIZ et al., 2005; HAUTRIVE et al., 2012), as well as reducing animal performance (SILVA et al., 2012). These changes are not appealing either to consumers concerned with healthy eating or to beef cattle producers.

Castration age can affect meat quality and animal performance, as it modulates the action of androgens, the main hormones responsible for the differences between bulls and steers (SEIDEMAN et al., 1982). The effects of castration age on animal performance and meat quality, although not fully elucidated, have been researched (MICOL et al., 2009; PRADO et al., 2014). However, little information concerning the fatty acid profile of the meat is available, especially for Nellore cattle. Therefore, the objective of the present study was to evaluate the fatty acid profile of the meat of young Nellore bulls or steers castrated at different ages.

\section{Materials and Methods}

The present study used the meat samples from the experimental animals used by Freitas et al. (2008). A total of 36 Nellore males were assigned to three treatments: steers castrated at 13 months (early rearing period) and 18 months (15 days before the termination period), and bulls. The animals were born between October and January and weaned at 12 months of age, with an average weight of $222 \pm$ $25.5 \mathrm{~kg}$. They were maintained (January to August) on Brachiaria brizantha cv. Marandu pasture with ad libitum mineral supplementation at will, keeping the stocking density fixed at two animals/ha. From August, the animals were confined in six lots (two lots per treatment) for 100 days. The animals were wormed before the experimental period and subjected to a 15-day period of adaptation to diet and facilities. After adaptation, the animals were weighed again, showing an average $290 \pm 20.5$ $\mathrm{kg}$ body weight at 19 months of age (assessed by dentition). The animals were fed ad libitum in three daily meals (administered at 8 a.m., 12 p.m., and 5 p.m.). The diet was composed (dry matter basis) of $53.7 \%$ dry matter, $12 \%$ crude protein, and $2.90 \mathrm{Mcal}$ of digestible energy, with a roughage/concentrate ratio of 60/40 (FREITAS et al., 2008).

The animals were slaughtered in a commercial abattoir under the supervision of the Federal Inspection Service, after fasting for 14-16h, following the normal slaughter line sequence. After slaughter, 
carcasses were identified, divided in half, weighed, washed, and cooled for 24 hours at temperatures between 0 and $2{ }^{\circ} \mathrm{C}$. Then, the longissimus dorsi muscle was removed from between the $9^{\text {th }}$ and $11^{\text {th }}$ ribs on the right housing. The marbling content ( 1 to $3=$ traces; 4 to $6=$ light; 7 to $9=$ small; 10 to $12=$ average; 13 to $15=$ moderate; 16 to $18=$ abundant) was determined in the cranial portion of this muscle after a 30-minute exposure to air (MÜLLER, 1987). The marbling score was $4.58,4.52$, and 3.18 points for steers castrated at 12 months, steers castrated at 18 months, and bulls, respectively. The amount of marbling was significantly lower in bulls than in steers, and similar between steers castrated at different ages (FREITAS et al., 2008).

The longissimus dorsi muscle was packed, identified, and frozen at $-18^{\circ} \mathrm{C}$. After 60 days, a steak with a thickness of $2.5 \mathrm{~cm}$ was removed from the cranial portion of the longissimus dorsi. The steaks were thawed at room temperature, dried in an oven with forced ventilation of air at $55{ }^{\circ} \mathrm{C}$ for 20 $\mathrm{h}$, and ground in a Wiley mill (to 1-mm particles). The total lipid content was determined by the hot extraction method with petroleum ether, in a Goldfisch extractor device for $5 \mathrm{~h}$ (AOAC, 1995).

Fatty acids were determined from the total lipid content, after the sample was saponified and the fatty acids were methylated following Hartman and Lago (1973). The supernatant (methyl esters) was subjected to gas chromatography, conducted in a gas chromatograph Thermo Electron Corporation Finnigan, model Focus GC, provided with a flame ionization detector, split injector, and a capillary column of fused silica DB-WAX (30 m length $\mathrm{x}$ $0.25 \mathrm{~mm}$ internal diameter x $0.25 \mu \mathrm{m}$ thickness, Restek, USA). The injector temperature was $230^{\circ} \mathrm{C}$, the detector temperature was $250^{\circ} \mathrm{C}$, and the initial temperature of the column was $200^{\circ} \mathrm{C}$ for $17 \mathrm{~min}$ and programmed to increase by $10^{\circ} \mathrm{C} / \mathrm{min}$ until it reached $230^{\circ} \mathrm{C}$, remaining stable for 10 more minutes. The carrier gas used was hydrogen, at a rate of $1.5 \mathrm{~mL} \mathrm{~min}^{-1}$. A $1-\mathrm{uL}$ volume and split in the ratio of 1:70 was injected. The data on the retention time and relative area percentage of peaks were obtained through the software ChromQuest version 4.1. The identification of fatty acids was performed by determining the retention times of methyl ester patterns of fatty acids (Supelco, 37-component FAME mix). These retention times were compared with the retention time of methyl esters of fatty acids contained in the analyzed samples and the equivalent chain length. The results were also compared through co-chromatography.

The experimental design was completely randomized with three treatments, using 12 repetitions. As the data satisfied the normality assumptions, they were subjected to an analysis of variance and orthogonal contrasts using the mixed model methodology (LITTEL et al., 2006), with $\alpha$ $=5 \%$. Means were compared by Tukey's test using SAS software (Statistical Analysis System, version 9.2). The square sum of treatments of the contrasts analysis was decomposed in orthogonal contrast: steers vs. bulls. The general mathematical model used was $\gamma_{\mathrm{ij}}=\mu+\tau_{\mathrm{i}}+\varepsilon_{\mathrm{ij}}$, where: $\gamma_{\mathrm{ij}}=$ dependent variable; $\mu=$ overall mean; $\tau_{\mathrm{i}}=$ treatment effect $i$; and $\varepsilon_{\mathrm{ij}}=$ residual experimental error.

\section{Results and Discussion}

The prevailing saturated fatty acids (SFAs) were C16:0 (26.39\%), C18:0 (24.39\%), and C14:0 (3.01\%), amounting to $53.79 \%$ of the fatty acids of the meat (Table 1). These fatty acids, as well as the amounts of the fatty acids C10:0, C12:0, C15:0, C23:0, C24:0 and the total SFAs were not altered by castration or by the age of castration (Table 1). The amounts of iC14:0, iC16:0, iC17:0, iC15:0, $\mathrm{aC} 15: 0$ and $\mathrm{aC} 17: 0$, which occurred at lower levels in the meat, were not altered by castration age, but were higher in bulls than in steers. These higher amounts of the iso (i) and anteiso (a) acids were observed by Padre et al. (2006) and explained by ruminal biohydrogenation. The amount of $\mathrm{C} 17: 0$, on the other hand, was lower in steers castrated at 18 mouths and did not differ among bulls and steers. 
Table 1. Variables related to saturated fatty acids of meat of Nellore steers castrated in different ages or bulls.

\begin{tabular}{|c|c|c|c|c|c|}
\hline \multirow{2}{*}{ Items } & \multicolumn{3}{|c|}{ Treatments } & \multirow{2}{*}{$\mathrm{SE}$} & \multirow{2}{*}{$\begin{array}{c}\mathrm{P} \text { - value } \\
\text { Steers vs. Bulls }\end{array}$} \\
\hline & S-13 & S-18 & Bulls & & \\
\hline C10:0 (Capric) & 0.05 & 0.06 & 0.06 & 0.006 & 0.380 \\
\hline C12:0 (Lauric) & 0.07 & 0.08 & 0.09 & 0.007 & 0.180 \\
\hline iC14:0 (iso-Myristic) & $0.06^{\mathrm{b}}$ & $0.06^{\mathrm{b}}$ & $0.08^{\mathrm{a}}$ & 0.004 & $<0.001$ \\
\hline C14:0 (Myristic) & 2.85 & 3.16 & 3.01 & 0.142 & 0.924 \\
\hline iC15:0 (iso-13-Methyltetradecanoic) & $0.17^{\mathrm{b}}$ & $0.17^{\mathrm{b}}$ & $0.21^{\mathrm{a}}$ & 0.011 & 0.011 \\
\hline aC15:0 (anteiso-12-Methyltetradecanoic) & $0.18^{\mathrm{b}}$ & $0.17^{\mathrm{b}}$ & $0.24^{\mathrm{a}}$ & 0.013 & $<0.001$ \\
\hline C15:0 (Pentadecylic) & 0.36 & 0.35 & 0.39 & 0.016 & 0.126 \\
\hline iC16:0 (iso-Palmitic) & $0.20^{\mathrm{b}}$ & $0.19^{\mathrm{b}}$ & $0.24^{\mathrm{a}}$ & 0.011 & 0.002 \\
\hline C16:0 (Palmitic) & 26.73 & 26.01 & 26.43 & 0.881 & 0.843 \\
\hline iC17:0 (iso-Margaric) & $0.32^{\mathrm{b}}$ & $0.33^{\mathrm{b}}$ & $0.36^{\mathrm{a}}$ & 0.013 & 0.010 \\
\hline $\mathrm{aC} 17: 0$ (anteiso-Margaric) & $0.44^{\mathrm{b}}$ & $0.43^{\mathrm{b}}$ & $0.51^{\mathrm{a}}$ & 0.023 & 0.007 \\
\hline C17:0 (Margaric) & $1.06^{\mathrm{a}}$ & $0.96^{\mathrm{b}}$ & $1.04^{\mathrm{ab}}$ & 0.030 & 0.666 \\
\hline C18:0 (Stearic) & 24.55 & 22.60 & 26.02 & 1.463 & 0.296 \\
\hline C20:0 (Arachidic) & $0.15^{\mathrm{b}}$ & $0.14^{\mathrm{b}}$ & $0.18^{\mathrm{a}}$ & 0.008 & 0.017 \\
\hline C23:0 (Tricosanoic) & 0.03 & 0.04 & 0.03 & 0.005 & 0.941 \\
\hline C24:0 (Lignoceric) & 0.02 & 0.02 & 0.02 & 0.002 & 0.078 \\
\hline Total saturated fatty acids & 56.54 & 54.77 & 58.91 & 1.680 & 0.086 \\
\hline
\end{tabular}

S-13 and S-18 = steers castrated with 13 and 18 months of age, respectively; Means followed by different letters in line differ by Tukey test $(\mathrm{P}<0.05) ; \mathrm{SE}=$ standard error; $\mathrm{P}=$ statistical probability.

An increase in SFA is not usually desired, as it increases the low-density lipoproteins (LDL) and high-density lipoproteins (HDL). The main SFAs are C14:0, C16:0, and C18:0. The fatty acid $\mathrm{C} 14: 0$ is hypocholesterolemic, $\mathrm{C} 16: 0$ has lower hypocholesterolemic action, and $\mathrm{C} 18: 0$ has no effect (HAUTRIVE et al., 2012). One of the few studies concerning the effect of castration age on the fatty acid profile of the beef found no changes in SFA content in the meat of Friesian bulls slaughtered at 12 months of age, or steers castrated at 15 days or five months of age (PRADO et al., 2014). Amount of SFA is directly associated with total fat of the carcass (WOOD et al., 2008), especially considering intramuscular fat (BRESSAN et al., 2011). The relationship between intramuscular fat and SFA content, however, was not observed in the present study, given that the amount of SFA in steer meat did not exceed that in bull meat, despite higher marbling.
It is assumed that the effect of age of castration on the fatty acid content in beef meat depends on the age relative to puberty when castration was performed and on the age and/or slaughter weight. These factors are crucial for the deposition of body fat, especially marbling, which tends to be greater at lower ages of castration (SEGATO et al., 2005) and higher with increasing age and/or slaughter weight (KUSS et al., 2005). The SFA content in ruminants should be considered the result of lipolysis, ruminal biohydrogenation, and a "new" synthesis (SMITH et al., 2009). The increase in fatty acids of lower representation in the meat of bulls, on the other hand, may indicate lower capacity of enzymatic desaturation. The expression of the acetyl-CoA carboxylase gene tends to be higher in steers than in bulls, which can compromise the "new synthesis" in bulls, as this enzyme catabolizes the carboxylation of acetyl-CoA to malonyl-CoA (BAIK et al., 2014). 
The comparison between bulls and steers is better represented in the literature than is the comparison of steers of different castration ages. Ruiz et al. (2005) reported higher levels of the fatty acid C18:0 in cross-Nellore steers castrated surgically $(22.0 \%)$ or by anti-GnRH vaccine (20.2\%) compared with bulls $(18.45 \%)$, and attributed this finding to the higher marbling content of the steers. The same authors also found that the fatty acid content of C14:0 was higher in immunized animals than in bulls, which had similar amounts of this acid as did surgically castrated steers. However, Fernandes et al. (2009) found that among the SFAs identified in Canchim bovine meat, only the fatty acid C15:0 was altered by castration, being higher in bulls than in steers. According to these researchers, the odd chain fatty acids are unusual in the lipids of most mammals. However, in ruminants, they are formed by a "new synthesis" from the propionic acid produced in the rumen. Nogalski et al. (2014) found no changes in total SFA content between Polish Holstein Friesian $x$ Limousin steers castrated at 2-3 weeks of age and bulls, which agrees with the findings of this study.

The fatty acid C18:1 $n 9$ appeared at a higher average level in the meat (34.54\%), consistent with the literature (SAMI et al., 2006; ROTTA et al., 2009). The high level of the fatty acid C18:1 $n 9$ is desirable because of its hypocholesterolemic effect (HAUTRIVE et al., 2012). The fatty acid C16:1 $n 7$ was the monounsaturated acid with the second highest average level (2.2\%). These fatty acids, along with the fatty acid C17:1 $n 9$, which appears at a low average level $(0.49 \%)$, had lower occurrence in bulls than in steers castrated at 18 months, and the two groups of steers did not differ significantly. Because of this, the monounsaturated fatty acid content (MUFA) was lower in bulls than in steers castrated at 18 months, which did not differ from steers castrated at 12 months. The increased marbling of the meat was confirmed to enhance MUFA by increasing C18:1 $n 9$, which was supported by the fact that the steers had greater marbling of meat than the bulls (SMITH et al., 2009). However, it is worth noting that gas chromatography using short columns (15-20 m) instead of larger columns $(100 \mathrm{~m})$, as in the present study $(30 \mathrm{~m})$, has the drawback of not separating geometric isomers, especially MUFA 18 C. Thus, the values obtained for the fatty acid C18:1 $n 9$ may be overestimated because they may include significant amounts of 18:1 trans 11 , as well as 18:1 $n 7$ from lengthening 16:1 $\mathrm{n}-7$. In addition, the fatty acids $\mathrm{C} 17: 0$ and $\mathrm{C} 17: 1 n 8$ and other fatty acids with minor peaks may be included in the amounts of the fatty acid C16:1 $n 7$ (SMITH et al., 2006). However, these results do increase our limited knowledge of the nutraceutical quality of meat at different ages.

Levels of the fatty acid C14:1 $n 5$ increased according to the age of castration; they were higher in steers castrated at 18 months than at those castrated at 12 months or bulls, which did not differ from each other (Table 2). Likewise, the amount of the fatty acid iC16:1 n5 was higher in steers castrated at 18 months. However, unlike the fatty acid C14:1 $n 5$, it presented an intermediate value in steers castrated at 12 months and was lower in bulls. In general, the analysis of contrasts showed that the fatty acids C14:1 $n 5$ and iC16:1 $n 5$ were higher in the meat of steers than in bulls. The fatty acid C14:1 $n 5$ is derived from the desaturation of C14:0 by the enzyme $\Delta^{9}$ desaturase. Likewise, the fatty acid C16:1 $n 7$, which occurs in moderately low levels in the diet, is concentrated in the adipose tissue according to the activity of the enzyme $\Delta^{9}$ desaturase (SMITH et al., 2006). Our finding that this fatty acid had the second highest average level may indicate greater activity of $\Delta^{9}$ desaturase in the steers. 
Table 2. Variables related to monounsaturated fatty acids of meat of Nellore steers castrated in different ages or bulls.

\begin{tabular}{lccccc}
\hline \multirow{2}{*}{ Items } & \multicolumn{3}{c}{ Treatments } & \multirow{2}{*}{ SE } & P - value \\
\cline { 2 - 3 } & S-13 & S-18 & Bulls & & Steers vs. Bulls \\
\hline C14:1 $n 5$ (Myristoleic) & $0.44^{\mathrm{b}}$ & $0.53^{\mathrm{a}}$ & $0.40^{\mathrm{b}}$ & 0.029 & 0.046 \\
C16:1 $n 7$ (Palmitoleic) & $2.18^{\mathrm{ab}}$ & $2.46^{\mathrm{a}}$ & $1.96^{\mathrm{b}}$ & 0.102 & 0.034 \\
iC16:1 $n 5$ (iso-Palmitoleic) & $0.10^{\mathrm{b}}$ & $0.12^{\mathrm{a}}$ & $0.08^{\mathrm{c}}$ & 0.007 & 0.004 \\
C17:1 $n$ 9 (cis-10-Heptadecanoic) & $0.50^{\mathrm{ab}}$ & $0.52^{\mathrm{a}}$ & $0.44^{\mathrm{b}}$ & 0.022 & 0.048 \\
C18:1 $n$ 9 (Oleic) & $34.80^{\mathrm{ab}}$ & $36.53^{\mathrm{a}}$ & $32.31^{\mathrm{b}}$ & 1.347 & 0.177 \\
C18:1 $n 7$ (cis-Vacenic) & $0.34^{\mathrm{b}}$ & $0.36^{\mathrm{b}}$ & $0.45^{\mathrm{a}}$ & 0.024 & 0.001 \\
C18:1 $n 5$ (cis-12-Octadecenoic) & 0.33 & 0.34 & 0.29 & 0.022 & 0.033 \\
C19:1 $n$ 11 (cis-8-Nonadecanoic) & $0.10^{\mathrm{ab}}$ & $0.08^{\mathrm{b}}$ & $0.11^{\mathrm{a}}$ & 0.008 & 0.123 \\
C19:1 $n$ 9 (cis-10-Nonadecanoic) & 0.06 & 0.08 & 0.07 & 0.005 & 0.472 \\
C18:1 $n 4$ (cis-14-Nonadecanoic) & 0.05 & 0.07 & 0.05 & 0.009 & 0.807 \\
C18:1 $n 3$ (cis-15-Nonadecanoic) & 0.15 & 0.16 & 0.14 & 0.006 & 0.133 \\
C20:1 $n 11$ (Gadoleic) & 0.09 & 0.10 & 0.09 & 0.004 & 0.777 \\
C20:1 $n$ (Gondoic) & 0.12 & 0.13 & 0.11 & 0.009 & 0.258 \\
C24:1 $n$ 9 (Nervonic) & $0.15^{\mathrm{ab}}$ & $0.12^{\mathrm{b}}$ & $0.20^{\mathrm{a}}$ & 0.023 & 0.020 \\
Total monounsaturated fatty acids & $39.41^{\mathrm{ab}}$ & $41.60^{\mathrm{a}}$ & $36.70^{\mathrm{b}}$ & 1.580 & 0.043 \\
\hline
\end{tabular}

S-13 and S-18 = steers castrated with 13 and 18 months of age, respectively; Means followed by different letters in line differ by Tukey test $(\mathrm{P}<0.05)$; $\mathrm{SE}=$ standard error; $\mathrm{P}=$ statistical probability.

The amount of the fatty acid C18:1 $n 7$, on the other hand, differed only between steers and bulls and was higher in bulls (Table 2). These results contrasted with the results presented by Rodrigues et al. (2004), who found no changes in fatty acid C18:1 $n 7$ between Nellore bulls and steers. On the other hand, Padre et al. (2006) found a higher content of fatty acid C18:1 $n 7$ in steers that were Nellore-Aberdeen crosses than in bulls, resulting from the higher levels of the fatty acids C16:0 and C16:1 $n 7$. The fatty acid C18:1 $n 7$ is synthesized by converting the fatty acid $\mathrm{C} 16: 0$ to $\mathrm{C} 16: 1 n 7$ by a desaturase $\Delta^{9}$, with subsequent action of an elongase enzyme (BARTHET, 2008). The results obtained in this regard are supported by the lower level of the fatty acid C16:1 $n 7$ in bulls, showing greater elongation of the fatty acid C16:1 $n 7$ toward the fatty acid $\mathrm{C} 18: 1 n 7$.

The amounts of C24:1 $n 9$ and C19:1 n9 (less common fatty acids) were lower in steers that were castrated at 18 months than in those castrated at 12 months, and were higher in both groups of steers than in bulls (Table 2). The increased levels of fatty acids C24:1 n9, C18:3 n3, C18:3 n6, and C20:2 n6 are desirable for protection against atherosclerosis and thrombotic disease (MULVIHILL, 2001). On the other hand, the levels of the fatty acids $\mathrm{C} 18: 1$ $n 5, \mathrm{C} 19: 1 n 9, \mathrm{C} 18: 1 n 4, \mathrm{C} 18: 1 n 3, \mathrm{C} 20: 1 n 11$, and C20:1 $n 9$, which were less common and/or appeared at lower levels in beef, were not altered by castration or castration age.

Only the fatty acids C16:3 $n 3, \mathrm{C} 16: 3 n 6, \mathrm{C} 18: 2$ $n 6, \mathrm{C} 18: 3 n 3, \mathrm{C} 18: 3 n 6$, and C20:2 $n 6$ among the di-unsaturated and polyunsaturated fatty acids were altered by castration and/or castration age (Table 3 ). The amounts of the fatty acids $\mathrm{C} 16: 3 n 3, \mathrm{C} 16: 3$ $n 6, \mathrm{C} 18: 3 n 6$, and $\mathrm{C} 20: 2 n 6$ in the meat differed only between bulls and steers and were higher for bulls. The amounts of the fatty acids C18:2 n6 and $\mathrm{C} 18: 3 n 3$ increased for steers that were older at castration, and was the same between bulls and the older-castration steers. Wood et al. (2008) 
reported that the amount of the fatty acid C18:2 $n 6$ declines with increasing fat deposition, because the phospholipid content decreases as the muscle lipid content increases, whereas the proportion of lipids that contain a higher content of SFA and MUFA increases. In humans, the fatty acids C18:2 $n 6$ and $\mathrm{C} 18: 3 n 3$ are necessary to maintain cell membranes, brain functions, and nerve impulse transmission and are classified as essential for the body (MARTIN et al., 2006).

Table 3. Variables related to di-unsaturated and polyunsaturated fatty acids of meat of Nellore steers castrated in different ages or bulls.

\begin{tabular}{|c|c|c|c|c|c|}
\hline \multirow{2}{*}{ Items } & \multicolumn{3}{|c|}{ Treatments } & \multirow{2}{*}{ SE } & \multirow{2}{*}{$\begin{array}{c}\text { P - value } \\
\text { Steers vs. Bulls }\end{array}$} \\
\hline & S-13 & S-18 & Bulls & & \\
\hline C16:2 n5 (cis-11,14-Octadecadienoic) & 0.03 & 0.03 & 0.05 & 0.009 & 0.138 \\
\hline C16:3 n6 (cis-4,7,10-Hexadecatrienoic) & $0.06^{\mathrm{b}}$ & $0.06^{\mathrm{b}}$ & $0.08^{\mathrm{a}}$ & 0.005 & 0.002 \\
\hline C16:3 n3 (cis-7,10,13-Hexadecatrienoic) & $0.18^{\mathrm{b}}$ & $0.18^{\mathrm{b}}$ & $0.20^{\mathrm{a}}$ & 0.007 & 0.003 \\
\hline C16:4 n3 (cis-4,7,10,13-Hexadecatetraenoic) & 0.15 & 0.16 & 0.22 & 0.027 & 0.091 \\
\hline C17:2 n5 (cis-9,12-Heptadecadienoic) & 0.02 & 0.02 & 0.02 & 0.001 & 0.173 \\
\hline C18:2 n4 (cis-11,14-Octadecadienoic) & 0.11 & 0.11 & 0.12 & 0.006 & 0.052 \\
\hline C18:2 n6 (Linoleic) & $1.46^{\mathrm{b}}$ & $1.70^{\mathrm{ab}}$ & $2.01^{\mathrm{a}}$ & 0.128 & 0.009 \\
\hline C18:3 n6 ( $\gamma$-Linolenic $)$ & $0.13^{\mathrm{b}}$ & $0.12^{\mathrm{b}}$ & $0.15^{\mathrm{a}}$ & 0.006 & 0.001 \\
\hline C18:3 n3 ( $\alpha$-Linolenic) & $0.16^{\mathrm{b}}$ & $0.19^{\mathrm{ab}}$ & $0.23^{\mathrm{a}}$ & 0.014 & 0.002 \\
\hline Morotic & 0.21 & 0.22 & 0.25 & 0.015 & 0.072 \\
\hline cis-11,14-Eicosadienoic & $0.03^{b}$ & $0.03^{\mathrm{b}}$ & $0.04^{\mathrm{a}}$ & 0.002 & 0.007 \\
\hline Mead & 0.03 & 0.03 & 0.04 & 0.005 & 0.167 \\
\hline dihomo- $\gamma$-Linolenic & 0.07 & 0.09 & 0.07 & 0.001 & 0.375 \\
\hline cis-11,14,17-Eicosatrienoic & 0.14 & 0.17 & 0.18 & 0.027 & 0.473 \\
\hline cis-5,8,11,14,17-Eicosapentaenoic (EPA) & 0.03 & 0.04 & 0.04 & 0.006 & 0.289 \\
\hline cis-13,16-Docosadienoic & 0.07 & 0.05 & 0.09 & 0.020 & 0.212 \\
\hline cis-4,7,10,13,16,19-Docosahexaenoic (DHA) & 0.02 & 0.02 & 0.02 & 0.004 & 0.312 \\
\hline Total di-unsaturated fatty acids (UFA) & $1.72^{\mathrm{b}}$ & $1.94^{\mathrm{ab}}$ & $2.33^{\mathrm{a}}$ & 0.135 & 0.004 \\
\hline Total polyunsaturated fatty acids (PUFA) & $2.90^{\mathrm{b}}$ & $3.22^{\mathrm{ab}}$ & $3.81^{\mathrm{a}}$ & 0.230 & 0.046 \\
\hline Total unsaturated fatty acids (UFA) & $42.31^{\mathrm{ab}}$ & $44.82^{\mathrm{a}}$ & $40.51^{\mathrm{b}}$ & 1.660 & 0.083 \\
\hline
\end{tabular}

S-13 and S-18 = steers castrated with 13 and 18 months of age, respectively; Means followed by different letters in line differ by Tukey test $(\mathrm{P}<0.05)$; $\mathrm{SE}=$ standard error; $\mathrm{P}=$ statistical probability.

The amounts of di-unsaturated and polyunsaturated fatty acids, and the ratio between these types of fatty acids, were increased by the increasing age of castration, and were equal between steers castrated at 18 months and bulls. These results are associated with the variation in C18:2 $n 6$ (diunsaturated) and C18:3 $n 3$ (polyunsaturated). The negative relation between total polyunsaturated fatty acids (PUFA) and intramuscular fat (low in the bulls) occurs due to the dilution of a relatively constant amount of phospholipids by increased triglycerides with increasing beef marbling, which reduces the amount of phospholipids that are extractable from the structural components of muscle cells rich in polyunsaturated acids (SAMI et al., 2006).

The total unsaturated fatty acids (UFA) content, however, was similar between bulls and steers 
castrated at 12 months, and did not differ from that of steers castrated at 18 months. The UFA level is mainly due to the variation in acid C18:2 $n 6$ (Table 4). Nevertheless, the MUFA/SFA and UFA/SFA ratios were higher in steers castrated at 18 months than in bulls, with no difference between bulls and steers castrated at 12 months. The PUFA/SFA ratio, in turn, was not altered by sexual condition and age of castration. This ratio may fall to 0.05 in breeds with greater fat deposition and rise above 0.5 in leaner breeds with double muscling. This variation is much greater than what could be obtained by changes in diet. Other than using lean breeds, the only way to improve the PUFA/SFA ratio in ruminants is to reduce ruminal biohydrogenation or provide supplementation with PUFA in a form that is protected from ruminal degradation (DARLEY et al., 2010).

Table 4. Variables on the relationship between the total fatty acids, and dimethylacetal of meat of Nellore steers castrated in different ages or bulls.

\begin{tabular}{|c|c|c|c|c|c|}
\hline \multirow{2}{*}{ Items } & \multicolumn{3}{|c|}{ Treatments } & \multirow{2}{*}{ SE } & \multirow{2}{*}{$\begin{array}{c}\text { P - value } \\
\text { Steers vs. Bulls }\end{array}$} \\
\hline & S-13 & S-18 & Bulls & & \\
\hline Polyunsaturated/di-unsaturated & $1.20^{\mathrm{b}}$ & $1.31^{\mathrm{ab}}$ & $1.49^{\mathrm{a}}$ & 0.093 & 0.048 \\
\hline Monounsaturated/saturated & $0.69^{\mathrm{ab}}$ & $0.76^{\mathrm{a}}$ & $0.62^{\mathrm{b}}$ & 0.046 & 0.041 \\
\hline Polyunsaturated/saturated & 0.05 & 0.06 & 0.06 & 0.005 & 0.314 \\
\hline Unsaturated/saturated & $0.74^{\mathrm{ab}}$ & $0.82^{\mathrm{a}}$ & $0.69^{\mathrm{b}}$ & 0.049 & 0.074 \\
\hline$n-6$ & $1.69^{\mathrm{b}}$ & $1.94^{\mathrm{ab}}$ & $2.27^{\mathrm{a}}$ & 0.138 & 0.009 \\
\hline$n-3$ & $0.42^{\mathrm{b}}$ & $0.47^{\mathrm{ab}}$ & $0.54^{\mathrm{a}}$ & 0.033 & 0.048 \\
\hline$n-6 / n-3$ & 4.02 & 4.13 & 4.20 & 0.174 & 0.715 \\
\hline Dimethylacetal (DMA) & 0.18 & 0.19 & 0.23 & 0.028 & 0.291 \\
\hline
\end{tabular}

S-13 and S-18 = steers castrated with 13 and 18 months of age, respectively; Means followed by different letters in line differ by Tukey test $(\mathrm{P}<0.05) ; \mathrm{SE}=$ standard error; $\mathrm{P}=$ statistical probability.

The acid groups of the $n-6$ and $n-3$ families increased with increasing age of castration, without differing between bulls and steers castrated at 18 months of age. The ratio between the two acid groups was not altered by castration or age of castration. In general, the $n-6 / n-3$ ratio was in the range 4 to $5 / 1$, considered ideal to promote benefits to human health. Ratios from $2 / 1$ to $3 / 1$ have been recommended due to the increased conversion of the acid C18:3 $n 3$ into $22: 5 n-6$, while ratios from 2 to $4 / 1$ are more important for health-conscious consumers, as they result in a low intake of 20:5 n-3 and 22:5 $n-6$. Ratios below $1 / 1$ are not recommended due to inhibiting the conversion of C18:2 $n 6$ in PUFA of very long chains ( $>20$ carbons), as reviewed by Martin et al. (2006).

The dimethyl acetal content (DMA) was not changed by the different treatments (Table 4). Bacterial lipids have a high proportion of branchedchain fatty acids, synthesized from propionate and/ or volatile branched-chain fatty acid derivatives of branched-chain amino acids and plasmogenic lipids, which have DMA (MIYAGAWA, 1982; VLAEMINCK et al., 2006). The presence of DMA indicates a pattern of rumen fermentation, in which the diet is the main determinant of ruminant meat quality (ALVES et al., 2013). These results are consistent since the animals were fed the same diet.

\section{Conclusions}

The meat of Nellore bulls has better nutraceutical characteristics than steers. On the other hand, the castration of Nellore cattle before the confinement 
finishing period increase the beneficial fatty acids to human health compared with castration of pubescent males.

\section{References}

ALVES, S. P.; SANTOS-SILVA, J.; CABRITA, A. R. J.; FONSECA, A. J. M.; BESSA, R. J. B. Detailed dimethylacetal and fatty acid composition of rumen content from lambs fed lucerne or concentrate supplemented with soybean oil. PLoS One, California, v. 8, n. 3, p. 1-14, 2013.

ASSOCIATION OF OFFICIAL ANALYTICAL CHEMISTS - AOAC. Official methods of analysis. $16^{\text {th }}$ ed. Washington: AOAC, 1995.

BAIK, M.; JEONG, J. Y.; THAO VU, T. T.; PIAO, M. Y.; KANG, H. J. Effects of castration on the adiposity and expression of lipid metabolism genes in various fat depots of Korean cattle. Livestock Science, New York, v. 168, s/n, p. 168-176, 2014.

BARTHET, V. J. (n-7) and (n-9) cis-Monounsaturated fatty acid contents of 12 Brassica species. Phytochemistry, New York, v. 69, n. 2, p. 411-417, 2008.

BRESSAN, M. C.; ROSSATO, L. V.; RODRIGUES, E. C.; ALVES, S. P.; BESSA, R. J. B.; RAMOS, E. M.; GAMA, L. T. Genotype $\times$ environment interactions for fatty acid profiles in Bos indicus and Bos taurus finished on pasture or grain. Journal of Animal Science, Champaign, v. 89, n. 1, p. 221-232, 2011.

DANIEL, C.; CROSS, A. J.; KOEBNICK, C.; SINHA, R. Trends in meat consumption in the USA. Public Health Nutrition, Cambridge, v. 14, n. 4, p. 575-583, 2010.

DARLEY, C. A.; ABBOT, A.; DOYLE, P. S.; NADER, G. A.; LARSON, S.; DE SEMET, S. R.; DEMEYER, D. A review of fatty acid profiles and antioxidant content in grass-fed and grain-fed beef. Nutrition Journal, London, v. 9 , n. 10 , p. 4-12, 2010.

DESTEFANIS, G.; BRUGIAPAGLIA, M. T.; BARGE, C.; LAZZARONI, C. Effect of castration on meat quality in Piemontese cattle. Meat Sience, Barking, v. 64, n. 2, p. 215-218, 2003.

FELÍCIO, P. E. Dois aspectos de competitividade da carne de Bos indicus, um positivo, outro negativo. CONGRESSO BRASILEIRO DAS RAÇAS ZEBUÍNAS, 1., 1994, Uberaba. Anais... Uberaba: Associação Brasileira de Criadores de Zebu, 1994. p. 6371.
FERNANDES, A. R. M.; SAMPAIO, A. A. M.; HENRIQUE, W.; TULLIO, R. R.; OLIVEIRA, E. A.; SILVA, T. M. Composição química e perfil de ácidos graxos da carne de bovinos de diferentes condições sexuais recebendo silagem de milho e concentrado ou cana-de-açúcar e concentrado contendo grãos de girassol. Revista Brasileira de Zootecnia, Viçosa, MG, v. 38, n. 4, p. 705-712, 2009.

FREITAS, A. K.; RESTLE, J.; PACHECO, P. S.; PADUA, J. T.; LAGE, M. E.; MIYAGI, E. S.; SILVA, G. F. R. Características de carcaças de bovinos Nelore inteiros vs castrados em duas idades, terminados em confinamento. Revista Brasileira de Zootecnia, Viçosa, MG, v. 37, n. 6, p. 1055-1062, 2008.

HARTMAN, L.; LAGO, R. C. A. Rapid preparation of fatty acid methyl esters from lipids. Laboratory Practice, Washington, v. 22, p. 475-477, 1973.

HAUTRIVE, T. P.; MARQUES, A. C.; KUBOTA, E. H. Avaliação da composição centesimal, colesterol e perfil de ácidos graxos de cortes cárneos comerciais de avestruz, suíno, bovino e frango. Alimentos e Nutrição, São Carlos, v. 23, n. 2, p. 327-334, 2012.

KUSS, F.; LÓPEZ, J.; RESTLE, J.; BARCELLOS, J. O.; MOLETTA, J. L.; PAULA LEITE, M. C. Qualidade da carne de novilhos terminados em confinamento e abatidos aos 16 ou 26 meses de idade. Revista Brasileira de Zootecnia, Viçosa, MG, v. 39, n. 4, p. 924-931, 2010.

KUSS, F.; RESTLE, J.; BRONDANI, I. L.; ALVES FILHO, D. C.; PEROTTONI, J.; MISSIO, R. L.; AMARAL, G. A. Composição física da carcaça e qualidade da carne de vacas de descarte de diferentes grupos genéticos terminadas em confinamento com distintos pesos. Revista Brasileira de Zootecnia, Viçosa, MG, v. 34, n. 4, p. 1285-1296, 2005.

LITTELL, R. C.; MILLIKEN, G. A.; STROUP, W. W.; WOLFINGER, R. D.; SCHABENBERGER, O. SAS ${ }^{\circledR}$ for Mixed Models. $2^{\text {th }}$ ed. Cary: SAS Institute Inc., 2006.

MARTIN, C. A.; ALMEIDA, V. V.; RUIZ, M. R.; VISENTAINER, J. E. L.; MATSHUITA, M.; SOUZA, N. F.; VISENTAINER, J. V. Ácidos graxos poliinsaturados ômega-3 e ômega-6: importância e ocorrência em alimentos. Revista de Nutrição, Campinas, v. 19, n. 6, p. 761-770, 2006.

MICOL, D.; OURY, M. P.; PICARD, B.; HOCQUETTE, J. F.; BRIAND, M.; DUMONT, R.; EGAL, D.; JAILLER, R.; DUBROEUCQ, H.; AGABRIEL, J. Effect of age at castration on animal performance, muscle characteristics and meat quality traits in 26-month-old Charolais steers. Livestock Science, New York, v. 120, n. 1-2, p. 116-126, 2009. 
MIYAGAWA, B. Cellular fatty acid and fatty aldehyde composition of rumen bacteria. The Journal of General and Applied Microbiology, Tokyo, v. 28, n. 5, p. 389-408, 1982.

MÜLLER, L. Normas para avaliação de carcaças e concurso de carcaças de novilhos. 2. ed. Santa Maria: UFSM, Imprensa Universitária, 1987. 31 p.

MULVIHILL, B. Ruminant meat as a source of conjugated linoleic acid (CLA). British Nutrition Foundation Nutrition Bulletin, London, v. 26, n. 4, p. 295-299, 2001.

NOGALSKI, Z.; GROTH, Z. W.; PURWIN, C.; SOBCZUK-SZUL, M.; MOCHOL, M.; POGORZELKAPRZYBYLEK, M.; WINARSKI, R. Effect of slaughter weight on the carcass value of young crossbred (Polish Holstein Friesian $\times$ Limousin) steers and bulls. Chilean Journal of Agricultural Research, Chillán, v. 74, n. 1, p. 59-66, 2014.

PADRE, R. G.; ARICETTI, J. A.; MOREIRA, F. B.; MIZUBUTI, I. Y.; PRADO, I. N.; VISENTAINER, J. V.; SOUZA, N. E.; MATSUSHITA, M. Fatty acid profile, and chemical composition of Longissimus muscle of bovine steers and bulls finished in pasture system. Meat Science, Barking, v. 74, n. 2, p. 242-248, 2006.

PEREIRA, P. R. R. X.; BARCELLOS, J. J.; GRÜNDLING, R. D. P.; CANOZZI, M. E. A.; MCMANUS, R. B. L. Chilled boneless beef international trade: a cluster analysis. Revista Brasileira de Zootecnia, Viçosa, MG, v. 42, n. 3, p. 220-230, 2013.

PRADO, I. N.; CAMPO, M. M.; MUELA, E.; VALERO, M. V.; CATALAN, O.; OLLETA, J. L.; SAÑUDO, J. C. Effects of castration age, dietary protein level and lysine/methionine ratio on animal performance, carcass and meat quality of Friesian steers intensively reared. Animal, London, v. 8, n. 9, p. 1561-1568, 2014.

RODRIGUES, V. C.; ANDRADE, I. F. Características físico-químicas da carne de bubalinos e de bovinos castrados e inteiros. Revista Brasileira de Zootecnia, Viçosa, MG, v. 33, n. 6, p. 1839-1849, 2004. Suplemento 1.

RODRIGUES, V. C.; BRESSAN, M. C.; CARDOSO, M. G.; FREITAS, R. T. F. Ácidos graxos na carne de búfalos e bovinos castrados e inteiros. Revista Brasileira de Zootecnia, Viçosa, MG, v. 33, n. 2, p. 434-443, 2004.

ROTTA, P. P.; PRADO, I. N. do.; PRADO, R. M. do.; MOLETTA, J. L.; SILVA, R. R. S.; PEROTTO, D. Carcass characteristics and chemical composition of the longissimus muscle of nellore, caracu and holsteinfriesian bulls finished in a feedlot. Asian-Australasian
Journal of Animal Science, Seoul, v. 22, n. 4, p. 598-604, 2009.

RUIZ, M. R.; MATSUSHITA, M.; VISENTAINER, J. V.; HERNANDEZ, J. A.; RIBEIRO, E. L. A.; SHIMOKOMAKI, M.; REEVES, J. J.; SOUZA, N. E. Proximate chemical composition and fatty acid profiles of Longissimus thoracis from pasture fed LHRH immunocastrated, castrated and intact Bos indicus bulls. South African Journal of Animal Science, Pretoria, v. 35, n. 1, p. 13-18, 2005.

SAMI, A. S.; KOEGEL, J.; EICHINGER, H.; FREUDENREICH, P.; SCHWARZ, F. J. Effects of the dietary energy source on meat quality and eating quality attributes and fatty acid profile of Simmental bulls. Animal Research, Les Ulis, v. 55, n. 4, p. 287-299, 2006.

SEGATO, S.; ELIA, C.; MAZZINI, C.; BIANCHI, C.; ANDRIGUETTO, I. Effect of castration age on carcass traits and meat quality of Simmental bulls. Italian Journal of Animal Science, Parma, v. 4, n. 2, p. 263-265, 2005.

SEIDEMAN, S. C.; CROSS, H. R.; OLTJEN, R. R.; SCHANBACHER, B. D. Utilization of the intact male for red meat production: a review. Journal of Animal Science, Champaign, v. 55, n. 4, p. 826-840, 1982.

SILVA, N. R.; FERREIRA, A. C. H.; FATURI, C.; SILVA, G. F.; MISSIO, R. L.; NEIVA, J. N. M.; ARAÚJO, V. L.; ALEXANDRINO, E. Desempenho em confinamento de bovinos de corte, castrados ou não, alimentados com teores crescentes de farelo do mesocarpo de babaçu. Ciência Rural, Santa Maria, v. 42, n. 10, p. 1882-1887, 2012.

SMITH, S. B.; GILL, C. A.; LUNT, D. K.; BROOKS, M. A. Regulation of fat and fatty acid composition in beef cattle. Asian-Australasian Journal of Animal Science, Seoul, v. 22, n. 9, p. 1225-1233, 2009.

SMITH, S. B.; LUNT, D. K.; CHUNG, K. Y.; CHOI, C. B.; TUME, R. K.; ZEMBAYASHI, M. Adiposity, fatty acid composition, and delta-9 desaturase activity during growth in beef cattle. Animal Science Journal, Tokyo, v. 77, n. 5, p. 478-486, 2006.

VLAEMINCK, B.; FIEVEZ, V.; CABRITA, A. R. J.; FONSECA, A. J. M.; DEWHURST, R. J. Factors affecting odd- and branched-chain fatty acids in milk: A review. Animal Feed Science and Technology, New York, v. 131, n. 3, p. 389-417, 2006.

WOOD, J. D.; ENSER, M.; FISHER, A. V.; NUTE, G. R.; SHEARD, P. R.; RICHARDSON, S. I.; HUGHES, S. I.; WHITTINGTON, F. M. Fat deposition, fatty acid composition and meat quality: A review. Meat Science, Barking, v. 78, n. 4, p. 343-358, 2008. 